\title{
Immunophenotypic and Genotypic Markers of Follicular Center Cell Neoplasia in Diffuse Large B-Cell Lymphomas
}

Bruce E. King, M.D., Carolyn Chen, M.D., Joseph Locker, M.D., Ph.D., ${ }^{1}$ Jeffrey Kant, M.D., Ph.D., Kazuhiko Okuyama, M.D., Brunangelo Falini, M.D., Steven H. Swerdlow, M.D.

Department of Pathology, University of Pittsburgh School of Medicine (BEK, CC, JL, JK, KO, SHS), Institute of Hematology, University of Perugia, Perugia, Italy (BF)

Diffuse large B-cell lymphomas (DLBCL) are a biologically and clinically heterogeneous entity. Although some DLBCL represent transformation of follicular lymphomas (FL), the proportion that is of follicular center cell (FCC) origin remains uncertain. Immunophenotypic and genotypic markers used to suggest a FCC origin for a lymphoma (bcl-6 and CD10 expression, lack of CD138 expression, bcl-2 rearrangements $[R]$ ) or to subdivide DLBCL (bcl-2 expresssion, bcl-6 R) were therefore investigated in 22 FL and 44 DLBCL using paraffin section immunostains and Southern blot/polymerase chain reaction analysis. All FL tested were bcl-6+ (19) and CD138- (22) with 16/19 also bcl-2 and CD10+ (classic phenotype), one bcl2+, CD10- (grade III) and two bcl2-, CD10+ (grade II or III). Bcl-2R was identified in 4/5 FL-GrI, 3/6 FL-GrII, and 1/3 FL-GrIII. Bcl-6R was found in $0 / 5,2 / 4$, and $0 / 3 \mathrm{FL}$, respectively. All but 3/41 DLBCL were bcl-6+ with 17/37 also bcl-2+ and CD10+. Three of these cases were also $\mathrm{CD138+}$. Twelve bcl-6+ cases were bcl-2+, CD10-, six bcl-2-, CD10+, and two bcl-2-, CD10-. The three bcl-6- cases were bcl-2+, CD138- and two were CD10+. Bcl-2R was identified in 5/27 DLBCL with $4 / 5$ bcl-2,$+ 3 / 4$ tested $\mathrm{CD10}+$ and $4 / 4$ bcl-6+. Bcl-6R was identified in 7/26 including three with a classic FL phenotype. The vast majority of DLBCL in this study have an immunophenotype that supports a FCC origin. Although the proportion of DLBCL that co-expressed bcl-6, CD10 and bcl-2 was lower than for the FL, absence of bcl-2 or CD10 may be associated with

Copyright () 2000 by The United States and Canadian Academy of Pathology, Inc.

VOL. 13, NO. 11, P. 1219, 2000 Printed in the U.S.A.

Date of acceptance: June 23, 2000

${ }^{1}$ Current affiliation: Department of Pathology, Albert Einstein College of Medicine.

Address reprint requests to: Steven H. Swerdlow, M.D., Division of Hematopathology, UPMC Health System, UPMC-Presbyterian, Room C606.1, 200 Lothrop Street, Pittsburgh, PA 15213-2582; phone: 412-6475191; fax: 412-647-4008; e-mail: swerdlowsh@msx.upmc.edu. higher grade FL. It is also possible that bcl-6 expression is not completely specific for a FCC origin. Only a minority of cases suggested postfollicular differentiation. Only a minority of DLBCL show bcl-2R, suggesting that many have a different molecular pathogenesis than most low-grade FL. Bcl-6R did not exclude a FCC origin.

KEY WORDS: BCL-2; BCL-6; CD10; CD138; diffuse large B-cell lymphoma; follicular lymphoma; germinal center

Mod Pathol 2000;13(11):1219-1231

Diffuse large B-cell lymphomas (DLBCL), as defined in the REAL and upcoming WHO lymphoma classifications, represent a heterogeneous entity that includes not only transformed (noncleaved or centroblastic) follicular center cell (FCC) lymphomas but also all other lymphomas composed of large and transformed B cells (1-3). The proposed WHO classification recognizes three relatively uncommon subtypes of DLBCL [mediastinal (thymic), intravascular, and primary effusion lymphoma] but the immunoblastic lymphomas, transformed/"high grade" marginal zone lymphomas of mucosaassociated lymphoid tissue (MALT) and presumably nodal types and all other types of transformed B-cell lymphomas are not distinguished from one another. The DLBCL were grouped together for two main reasons. First, it was difficult to reproduce some of the previously described morphologic distinctions (such as those between transformed FCC lymphomas and immunoblastic lymphomas). Second, it was unclear how, for example, large noncleaved (LNC) FCC/centroblastic lymphomas should be distinguished from transformed marginal zone lymphomas of MALT type in the absence of a low-grade component.

Nevertheless, there is a large body of evidence suggesting that there are clinically and biologically distinctive types of DLBCL not specifically recog- 
nized in the most recent classifications. Although the older literature is filled with conflicting studies, recent investigations using strict criteria have demonstrated centroblastic (LNC FCC) lymphomas to have a better prognosis than immunoblastic lymphomas, a distinction even made in the National Cancer Institute working formulation but with imprecise criteria (4-6). From a biologic perspective, one of the major ways in which the B-cell lymphomas are divided is whether they are of prefollicular origin (e.g., mantle cell lymphomas), follicular origin (the FCC lymphomas), or postfollicular origin (probably the marginal zone lymphomas). Immunophenotypic methods have played an important role in the categorization of B-cell lymphomas into those of FCC or non-FCC origin because there are antigens that, even if not completely specific, characterize FCC as well as pre- and post-FCC. CD10 is expressed by precursor B cells as well as normal and many neoplastic FCC (7-13). Bcl-2 protein expression is another characteristic feature of neoplastic follicular centers, although there are many other normal and neoplastic bcl-2-positive lymphoid cells (14-24). More recently, bcl-6 expression (which characterizes FCC) and CD138 (syndecan) (which is a plasma-cell-associated antigen) have been used to divide the HIV-associated lymphomas into those of follicular origin (bcl-6+/CD138-) and those of postfollicular origin (bcl-6-/CD138+) (25). Genotypic studies are also important in categorizing and understanding these lymphomas. Bcl-2 rearrangements are a genotypic feature strongly associated with follicular lymphomas and also reported in less than 10 to $40 \%$ of DLBCL often without knowledge of whether they have other FCC characteristics $(22,26-34)$. DLBCL have also been subdivided based on whether they have bcl- 6 rearrangements with possible clinical and prognostic implications but without known implications as to their cell of origin $(28,30,35-43)$. Previous studies have investigated these immunophenotypic and genotypic markers in DLCBL but, to the best of our knowledge, all of them have not been used together in a single study. The concept of using clusters of gene expression to subdivide and characterize the DLBCL is highlighted in the very recent study of DLBCL using DNA microarrays (44). This study revealed two similarly sized prognostically different subgroups, one in which the cells have a gene expression pattern of germinal center cells and others that express genes associated with in vitro activation of peripheral blood B cells.

A multiparameter phenotypic and genotypic investigation was therefore undertaken to determine how many DLBCL not known to be associated with HIV infection seem to be of FCC origin and also to investigate how the different FCC and follicular lymphoma markers correlate with one another. In addition to CD10, bcl-6, bcl-2, and CD138 immunostains and Southern blot analysis for bcl-2 rearrangements, Southern blot analysis for bcl-6 rearrangements was performed because, as noted above, they have also been used to subdivide the DLBCL into two major groups. The results for the DLBCL were compared with those for a group of follicular lymphoma (FL) of varying grades.

\section{MATERIALS AND METHODS}

\section{Case Selection}

Cases of FL and diffuse DLBCL diagnosed between 1996 and1998 were identified by searching the medical archival retrieval system (MARS) at UPMC-Montefiore/Presbyterian Hospitals. An attempt was made in particular to find FL lacking CD10 or bcl-2 protein expression. Patients that were known to be HIV-positive were excluded from the study. Among the patients with DLBCL, one had a previous FL; one a history of an indolent lymphoma not otherwise specified; one a history of Hashimoto's thyroiditis; one a history of an "abnormal immune response"; six previous DLBCL; two a definite or probable previous lymphoma, not otherwise specified; and two biopsies were from the same patient. Histologic sections were reviewed in all cases together with any preexisting immunophenotypic data and the cases classified according to the REAL classification system (1). Cases were originally classified using the Lukes/Collins classification (data not shown) (45). Only two of the DLBCL showed immunoblastic features and one anaplastic large cell features. Some of the follicular lymphomas were included in a previous study of small B-cell lymphomas (9).

\section{Immunohistochemistry}

Paraffin section immunohistochemistry stains were performed on deparaffinized formalin (55 cases) or B5 fixed tissue sections (11 cases) using CD20, CD3, CD10, bcl-2, bcl-6, and CD138 antibodies and a streptavidin-biotin-peroxidase technique with the Ventana Immunostainer (Ventana Medical Systems, Tucson, AZ, USA), a biotin-Vector Elite $\mathrm{ABC}$ with the Cadenza Immunostainer (Shandon, Pittsburgh, PA) or a manual avidin-biotin complex method as summarized in Table 1. Antibodies were incubated for 1 hour using the latter method. Some antibodies required antigen retrieval by microwave heat and/or enzyme pretreatment. B5-fixed blocks were used only in cases where formalin-fixed blocks were not available.

CD20 and CD3 stains were tabulated as positive or negative without any equivocal cases. Bcl-6 was considered positive only when there was nuclear 
TABLE 1. Immunohistologic Stains

\begin{tabular}{|c|c|c|c|c|c|}
\hline Antigens & Method & Antibody & Titer & Source & Pretreatment \\
\hline CD20-Formalin-fixed & $\mathrm{V}^{a}$ & L26 & $1: 120$ & Dako, Carpinteria, CA & Microwave in citrate buffer $^{b}$ \\
\hline CD20-B5 fixed & $\mathrm{V}^{a}$ & L26 & $1: 120$ & Dako & No pretreatment required \\
\hline CD3 & $\mathrm{V}^{a}$ & Polyclonal & $1: 400$ & Dako & $\begin{array}{l}\text { Microwave plus Ventana protease } \\
2 \text { treatment } \times 4 \text { min. } .^{b}\end{array}$ \\
\hline CD10 & $\mathrm{C}$ & $\begin{array}{c}\text { NCL-CD10 } \\
\text { (56C6) }\end{array}$ & $1: 10$ & Novocastra/Vector, Burlingame, CA & $\begin{array}{l}\text { Microwave in citrate buffer }{ }^{b} \\
\text { tyramide enhancement } \\
\text { (NEN Life Sciences Products, } \\
\text { Boston, MA) }\end{array}$ \\
\hline CD138 & M & $\mathrm{B}-\mathrm{B} 4^{c}$ & $1: 20$ & Harlan Bioproducts, Burlingame, CA & Microwave in citrate buffer ${ }^{d}$ \\
\hline BCL-2 & $\mathrm{C}^{a}$ & 124 & $1: 10$ & Dako & Microwave in citrate buffer ${ }^{b, d}$ \\
\hline BCL-6 & M & PG-B6p & $1: 2$ & Prof. B. Falini & Microwave in Tris-EDTA buffer ${ }^{e}$ \\
\hline
\end{tabular}

${ }^{a}$ In some cases, a manual method was used for these antibodies. CD3 was used manually at a titer of 1:250 and with protease but no microwave pretreatment. No pretreatment was used for the manual CD20 stains. See ${ }^{d}$ for manual bcl-2 pretreatment.

${ }^{b}$ Microwave pretreatment was in $10 \mathrm{mM}$ citrate at $\mathrm{pH} 6.0$ for 15 minutes followed by 30 minutes to cool.

${ }^{c}$ Normal human serum (3\%) was added to the anti-CD138 antibody during incubation.

${ }^{d}$ Manual method included microwave pretreatment in $10 \mathrm{mM}$ citrate, $\mathrm{pH} 6.0,2 \times 5$ minutes followed by 60 minutes to cool.

${ }^{e}$ Microwave pretreatment in $1 \mathrm{mM}$ EDTA, pH $8.02 \times 5$ minutes followed by 60 minutes to cool.

staining in $\geq 20 \%$ of what were considered to be the neoplastic cells. Cases with only cytoplasmic staining were considered negative. Some cases that were CD10 negative did show extensive reticular staining and/or granular cytoplasmic staining. CD138 was considered positive only when there was strong surface staining similar to that of plasma cells. Some of the negative cases showed weak or equivocal cytoplasmic or Golgi-type positivity or scattered positive plasma cells. One FL had stronger cytoplasmic staining. CD138 also showed positivity in other non-neoplastic cells, including some epithelial cells and histiocytes.

\section{Cell Suspension Immunophenotypic Studies}

Flow cytometric immunophenotypic studies (FCIPS) had been previously performed on $22 \mathrm{FL}$ and 34 DLBCL cell suspensions using methods similar to those previously reported (9). The CD10 results (obtained from a tube also containing CD5 and CD19 antibodies) were compared with those from the paraffin section immunostains in cases where the flow cytometric immunophenotypic studies clearly identified the neoplastic B-cell population.

\section{Molecular Genotypic Studies}

Genotypic studies for immunoglobulin heavy chain (IgH), bcl-2, bcl-6, and, in one case, c-myc rearrangement were performed on DNA prepared from fresh or frozen samples when available. These studies included Southern blot analysis for rearrangements involving IgH, bcl-2, bcl-6, and c-myc, and in many cases polymerase chain reaction (PCR) for rearrangements at IgH or bcl-2 (major breakpoint) loci. Southern blot studies employed probes directed at the J region of the IgH locus, major and minor breakpoint regions of bcl-2, the translocation region of bcl-6, and exon 2 of c-myc. Three cases lacking an IgH rearrangement were excluded from further analyses because the DNA preparations were considered potentially nonrepresentative. In all but two cases with bcl-2 results reported, Southern blot analysis with or without PCR analysis was performed (one positive and one negative DLBCL studied only by PCR). Two of the bcl-2 rearrangements found involved the minor breakpoint region (both FL).

Genomic DNA was isolated from specimens by proteinase $\mathrm{K}$ digestion and extraction with phenol and chloroform. DNA (5 $\mu \mathrm{g}$ ) was digested under conditions recommended by the supplier (New England BioLabs, Beverly, MA, USA) with restriction enzymes BglII and BamHI (IgH), PstI and BamHI (bcl-2), BamHI and $\mathrm{Xba \textrm {I }}$ (bcl-6) and BamHI and EcoRI (c-myc). Additional restriction enzymes for IgH rearrangement studies were employed if necessary. Digestion was done with 10 to $20 \mathrm{U} / \mu \mathrm{g}$ DNA of restriction enzyme for 4 hours. Blue sucrose was added to samples that were then loaded on 0.5 to $0.7 \%$ agarose gels and electrophoresed for 16 hours at 40 to $60 \mathrm{~V}$ using Tris/acetate/EDTA buffer. Random primer labeling (Boehringer Mannheim $\mathrm{GmbH}$, Germany) with $\left[{ }^{32} \mathrm{P}\right] \mathrm{dATP}$ and $\left[{ }^{32} \mathrm{P}\right] \mathrm{dCTP}$ was performed to a specific activity of more than $4.0 \times 10^{8} \mathrm{dpm} / \mu \mathrm{g}$. After prehybridization, Southern blots were hybridized at $42^{\circ} \mathrm{C}$ in a $0.75 \mathrm{M}$ ionic strength solution containing $50 \%$ deionized formamide and then washed 3 times for 30 minutes at $52^{\circ} \mathrm{C}$ in a high-salt wash solution of $300 \mathrm{~mm}$ sodium chloride and $1 \%$ sodium dodecyl sulfate. Blots were then washed an additional 3 times for $1 \mathrm{~h}$ at $52^{\circ} \mathrm{C}$ in a low-salt wash solution of $15 \mathrm{~mm}$ sodium chloride and $1 \%$ sodium dodecyl sulfate. Blots were subjected to autoradiography using Kodak XAR-5 or BioMax MS type films with a single Dupont Cronex Lightning Plus screen or a Kodak BioMax MS intensifying screen for 28 to $72 \mathrm{~h}$. 


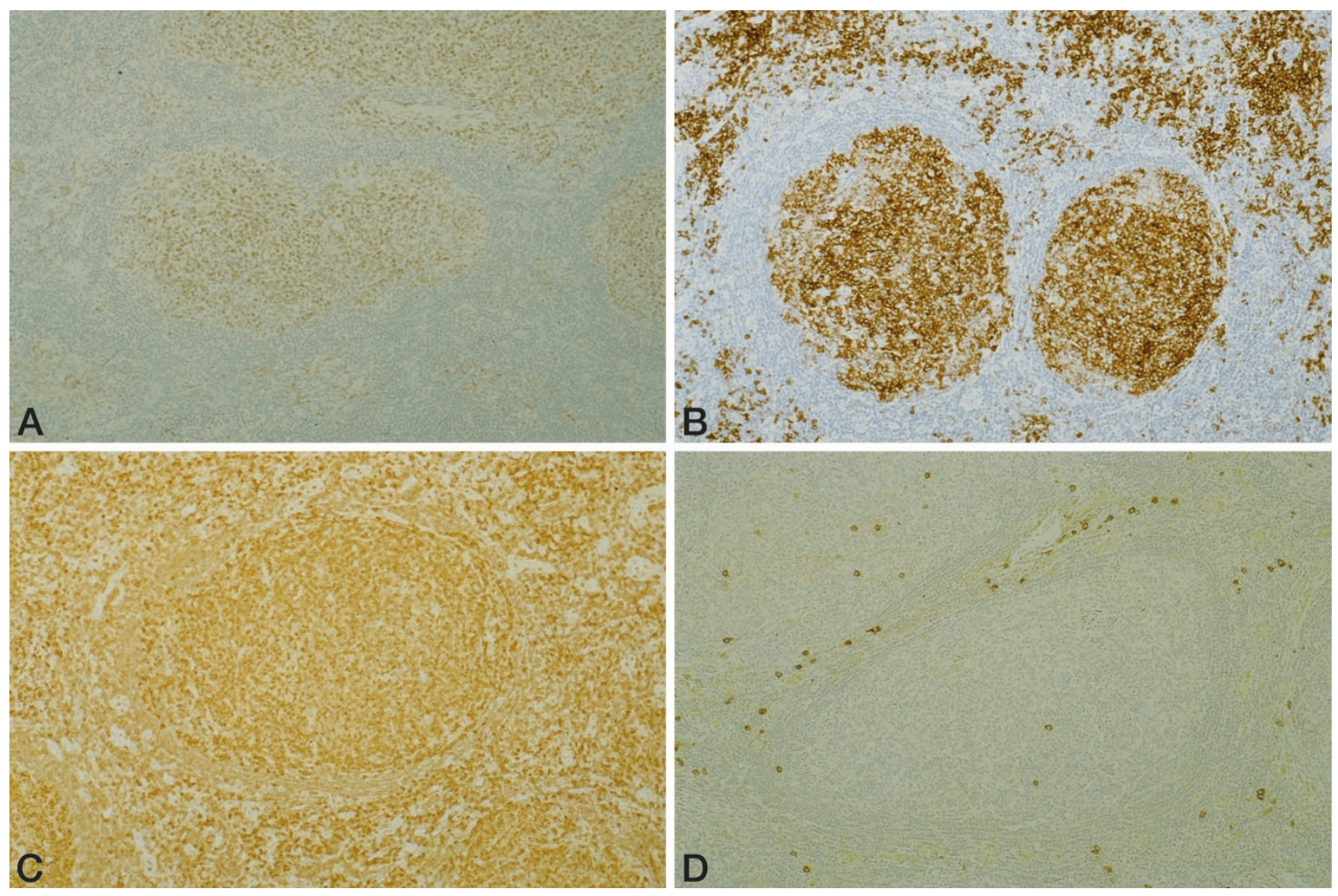

FIGURE 1. This follicular lymphoma demonstrates a bcl-6+ (A), CD10+ (B), bcl-2+ (C), and CD138- (D) phenotype. There are scattered CD138+ plasma cells. (Immunoperoxidase with hematoxylin counterstain.)

PCR studies were performed in 25 or $50 \mu \mathrm{L}$ reaction volumes by adding 100 to 300 ng of DNA to a PCR master mix consisting of buffer, magnesium chloride, dNTPs, appropriate primers (framework III and consensus J mix for IgH, bcl-2 mbr region, and consensus J mix for bcl-2) and $1.0 \mathrm{U} /$ reaction of Taq polymerase (Roche Molecular Systems). After 5 minutes of denaturation at $95^{\circ} \mathrm{C}$, for IgH PCR the mixture was then subjected to 35 cycles on the thermocycler $\left(95^{\circ} \mathrm{C}\right.$ for 15 seconds, $52^{\circ} \mathrm{C}$ for $20 \mathrm{sec}-$ onds, $72^{\circ} \mathrm{C}$ for 30 seconds) followed by an additional 5 minutes extension at $72^{\circ} \mathrm{C}$. After 5 minutes denaturation at $95^{\circ} \mathrm{C}$, for bcl-2 PCR the mixture was then subjected to 35 cycles on the thermocycler $\left(95^{\circ} \mathrm{C}\right.$ for 15 seconds, $60^{\circ} \mathrm{C}$ for 20 seconds, $72^{\circ} \mathrm{C}$ for 30 seconds) followed by an additional 5 -minute extension at $72^{\circ} \mathrm{C}$. Samples were then run on $8 \%$ acrylamide $(\mathrm{IgH})$ or $2 \%$ agarose (bcl-2) gels and stained with SYBR Green (IgH) or ethidium bromide (bcl-2) (Molecular Probes, Eugene, Oregon) before photographing. MspI digests of pBR322 (New England Biolabs, Inc., Beverly, MA) were used as molecular mass standards.

\section{Statistical Analysis \\ $\chi^{2}$ test was performed using StatView 4.5 (Abacus Concepts, Berkeley, CA, USA).}

\section{RESULTS}

\section{Follicular Lymphoma (FL)}

All FL were CD20-positive with variable numbers of admixed small CD3-positive cells. All FL tested were also bcl-6-positive with all but two CD10positive and all but three bcl-2-positive (Figure 1) (Tables 2, 3). The CD10 negative cases were both of grade III and the bcl-2 negative (2) or equivocal (1) cases grade II or III. None were CD138-positive, although positive plasma cells were seen in some cases. One FL, grade III, did show extensive cytoplasmic staining that was of uncertain significance. In 21 evaluable cases, flow cytometric determination of CD10 was the same as the immunostain evaluation (19/21 positive).

TABLE 2. Immunophenotype and Genotype of Follicular Lymphomas

\begin{tabular}{lccccccc}
\hline & Total & Bcl-6+ & Bcl-2+ & CD10 $€$ D138+ & Bcl-2 $\mathrm{R}^{c}$ & Bcl-6 R \\
\hline Nodal & 19 & $16 / 16$ & $17 / 19^{a}$ & $17 / 19$ & $0 / 19$ & $8 / 12$ & $2 / 11$ \\
Extranodal & 3 & $3 / 3$ & $2 / 3$ & $3 / 3$ & $0 / 3^{b}$ & $0 / 2$ & $0 / 1$ \\
\hline
\end{tabular}

The extranodal lymphomas were from the retroperitoneum, skin (left deltoid), and soft tissue (right neck). R, clonal rearrangement.

${ }^{a}$ One of the two negative cases showed equivocal staining.

${ }^{b}$ One had extensive cytoplasmic CD138 positivity.

${ }^{c}$ Only includes results for cases with documented immunoglobulin heavy-chain rearrangement. 
TABLE 3. Correlation of Immunophenotypic Profiles, Grade, and Genotype for Follicular Lymphomas

Grade I Grade II Grade III Bcl-2-R ${ }^{b}$ Bcl-6- $\mathrm{R}^{b}$

\begin{tabular}{llllll}
\hline Bcl-6+, bcl-2+, CD10+ & 8 & 5 & 3 & $8 / 13^{a}$ & $2 / 12^{a}$
\end{tabular}

Bcl-6+, bcl-2+, CD10- $0 \quad 0 \quad 1 \quad 0 / 0 \quad 0 / 0$

Bcl-6+, bcl-2-, CD10+ $\begin{array}{lllll}0 & 1 & 1 & 0 / 1 & 0 / 0\end{array}$

All cases were CD138 negative. This table does not include two grade I (CD10+, bcl-2+) and one grade III (CD10- bcl-2 equivocal) follicular lymphoma because lacked bcl-6 stains. No molecular data is available for these three cases.

${ }^{a}$ One case had both bcl-2 and bcl-6 rearrangements.

${ }^{b}$ Only includes results for cases with documented immunoglobulin heavy-chain rearrangement.

Bcl-6 showed nuclear staining usually on at least $80 \%$ of the cells (others $>50$ to $>70 \%$ ) with several cases showing greater staining in the follicles than in the interfollicular areas. B5 fixed sections tested in two cases showed weak staining in one and stronger staining in the other.

$\mathrm{Bcl}-2$ gene rearrangements $(\mathrm{R})$ were identified in 8/14 FL (4/5 GrI, 3/6 GrII, and 1/3 GrIII) (Tables 2 and 3). All of the rearranged cases had a classic FL phenotype; however, only one case lacking bcl-2 was studied. Bcl-6R were found in 2/12 FL, both bcl-6-, CD10-, and bcl-2-positive, nodal, grade II and including one case that also had a bcl-2R.

\section{DLBCL}

All DLBCL were CD20-positive with variable numbers of admixed small CD3-positive cells. Bcl-6 was positive in all but three tested cases (93\%) with CD10-positive cells in 26/42 (62\%) and bcl-2positive cells in 34/42 cases (81\%) (Figure 2; Tables 4 and 5). All combinations except for a triplenegative phenotype were identified with the most common phenotype bcl-6+, bcl- $2+$, CD10+ followed by bcl-6+, bcl-2+, CD10-, and bcl-6+, bcl$2-, \mathrm{CD} 10+$ (Table 5). No significant differences were found for these markers between the nodal and extranodal cases. CD138 was positive in three extranodal cases that were also bcl-6, bcl-2, and CD10-positive. In two, the positivity was patchy, whereas the bcl-6 positivity was throughout (same patient), and in one, the CD138 positivity was mostly outside of the vaguely nodular areas where there was little bcl-6 staining. In 29 evaluable cases, flow cytometric determination of $\mathrm{CD} 10$ was the same as the immunostain evaluation (17/29 positive).

Bcl-6-positive DLBCL usually had more than 70 to $80 \%$ positive nuclei, although some had fewer $(>20$ to $>50 \%)$. Staining in B5 fixed sections was sometimes weak with repeated staining in
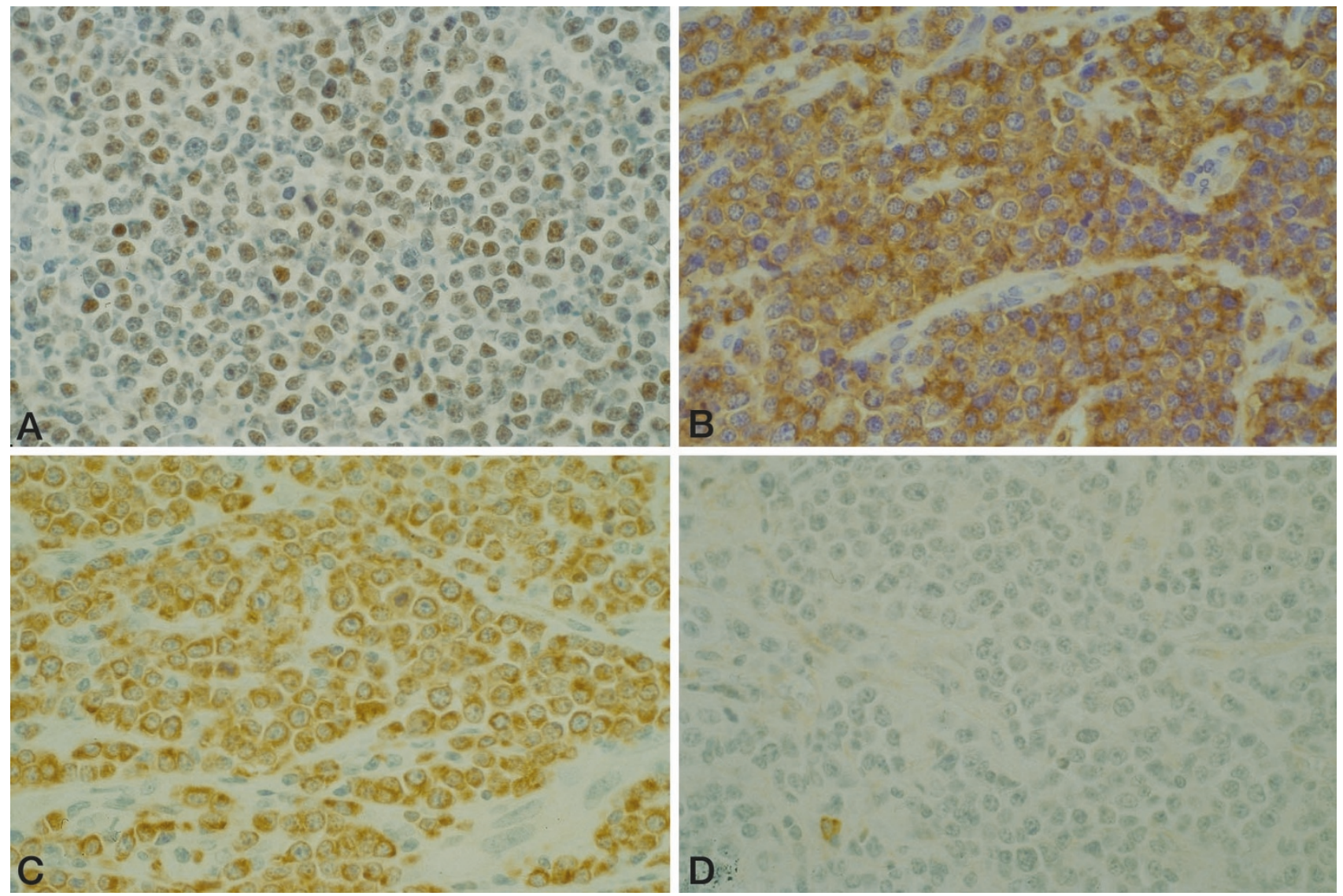

FIGURE 2. This diffuse large B-cell lymphoma also has a classic bcl-6+ (A), CD10+ (B), bcl-2+ (C), and CD138- (D) phenotype. (Immunoperoxidase with hematoxylin counterstain.) 


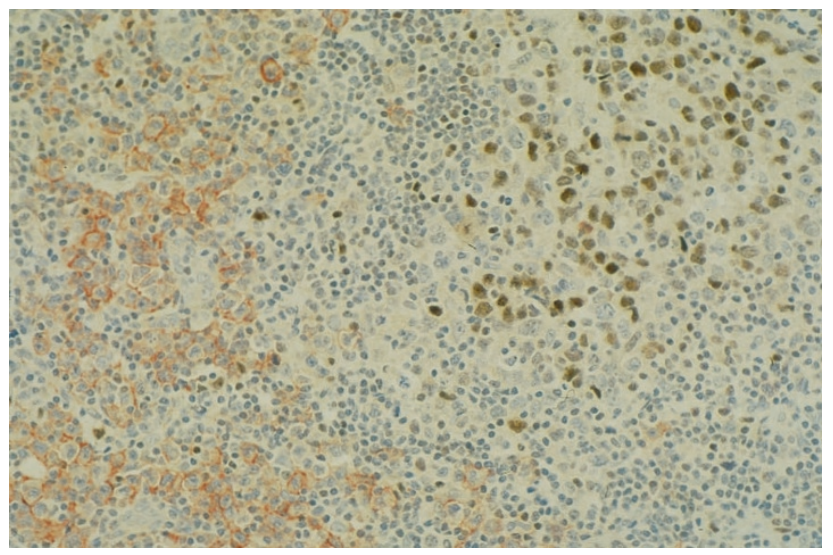

FIGURE 3. Note the distinct populations of bcl-6-positive (black nuclear staining) and CD138-positive (red membrane staining) cells in this diffuse large B-cell lymphoma. (Double immunostain with hematoxylin counterstain.)

formalin-fixed sections stronger (data not shown); however a formalin-fixed block was available in all but one of the negative cases. CD10+ cases usually showed staining on the vast majority of cells. Bcl-2+ cases also usually showed staining of the vast majority of cells, although in four positive cases only, more than 20 to $30 \%$ of the cells were stained; in one case, only focal areas showed positivity. Negative cases did have some positive cells, at least many of which may have been $\mathrm{T}$ cells.

Bcl-2R were identified in 5/27 cases including nodal and extranodal cases (Tables 4 and 5). All tested were bcl-6+. Three of four were $\mathrm{CD10}+$ (3/14 CD10+ versus $1 / 10$ CD10-) and 4/5 bcl-2+ with the bcl-2- case showing equivocal but probably negative staining (4/19 bcl-2+ versus $1 / 7$ bcl$2-)$. None tested were CD138-positive. The phenotypic differences were not significant although the numbers are small. Bcl-6R were found in 7/20 extranodal cases and $0 / 6$ nodal cases $(P=.09)$. All were bcl-6+, 4/7 CD10+ (4/14 CD10+ versus 3/10 CD10-) and all but one bcl-2-positive (6/18 bcl-2+ versus $1 / 7 \mathrm{bcl}-2-$ ) (Table 5 ). None of these phenotypic differences for bcl-2R or bcl-6R were statistically significant.

\section{DISCUSSION}

The vast majority of malignant lymphomas composed of large transformed B cells are now categorized as DLBCL in the REAL and upcoming WHO classifications, with mediastinal, intravascular, and primary effusion lymphomas the only recognized subtypes (1-3). Nevertheless, it is well known that DLBCL are a biologically and clinically heterogeneous group of lymphomas. DLBCL may be composed of LNC/centroblastic (CB) FCC, immunoblasts or other types of transformed B cells that are even more difficult to define. Many DLBCL diag- nosed as LNC/CB lymphomas often had little objective evidence of a FCC origin. Recent studies have once again suggested that immunoblastic lymphomas are more aggressive than other DLBCL $(4,5)$; that those with bcl-2 protein expression are more aggressive $(33,46-49)$; that those with a FCC pattern of gene expression do better than those with an activated B-cell phenotype (44); and that bcl-6R may identify a clinically distinct group (37, $40,41,50)$.

DLBCL, as well as FL, were therefore analyzed using a series of antigenic and oncogenic markers associated with follicular or postfollicular differentiation, associated with FL or previously used to subdivide DLBCL in an attempt to better determine how many DLBCL have phenotypic and genotypic features characteristic of FCC lymphomas and to compare the different markers. Other studies have used these markers alone or in limited combination to study either DLBCL in general or in specific patient subsets. More than $40 \%$ of the DLBCL studied here expressed a bcl-6+, bcl- $2+$, CD10+ phenotype identical with that found in the vast majority of the FL plus an additional 15\% of the DLBCL lacked only bcl-2. Even more striking, like all the FL, more than $90 \%$ of the DLBCL expressed bcl-6. Bcl-6 (B-cell lymphoma 6, also known as bcl-5 and Laz3), a Pox virus and zinc finger sequence-specific transcriptional repressor that recruits a repressing complex, is necessary for the development of germinal centers (51-56). Bcl-6 expression is found in normal follicular center cells but not in mantle cells, most marginal zone cells, or other pre- or postfollicular B cells $(25,52,57-61)$. Bcl-6 is also expressed by some cortical thymocytes, about $10 \%$ of intrafollicular $\mathrm{T}$ cells, and fewer than $0.5 \%$ of interfollicular CD4+ T cells (60). FL are uniformly bcl-6+, as supported by this study $(39,58,60-62)$. The finding here of bcl-6 expression in a very high proportion of DLBCL suggests, therefore, that most are of FCC origin, consistent with some other studies $(60,63)$. Others also report the majority of DBLCL to be bcl- $6+$ but with a smaller proportion of positive cases $(39,64)$. The

TABLE 4. Immunophenotype and Genotype of Diffuse Large B-Cell Lymphomas

\begin{tabular}{|c|c|c|c|c|c|c|c|}
\hline & Total & Bcl-6+ & Bcl-2+ & $\mathrm{CD} 10+$ & CD138+ & $-\mathrm{Bcl}-2 \mathrm{R}+{ }^{b}$ & Bcl-6 R+ ${ }^{b}$ \\
\hline & 11 & $8 / 9$ & & $4 / 10$ & $0 / 11$ & $2 / 7$ & $0 /$ \\
\hline Extranodal & 33 & $30 / 32$ & $25 / 32^{a}$ & $22 / 32$ & $3 / 31$ & $3 / 20$ & $7 / 20$ \\
\hline
\end{tabular}

The extranodal sites included the following: soft tissue (orbit, neck-3, temporal, abd)-6, thyroid-3, bowel (1 large and 1 small)-2, salivary gland-2, skin-2, soft tissue/bone and periosteum-2, tongue-2 and one specimen each from bronchus, conjunctiva, groin mass, kidney, liver, maxillary sinus, nasal mass, skeletal muscle (arm), soft palate, sphenoid, spleen, stomach, testicle, and vocal cord.

$\mathrm{R}$, clonal rearrangement.

${ }^{a}$ One case considered negative showed equivocal staining.

${ }^{b}$ Only includes results for cases with documented immunoglobulin heavy chain rearrangement. 


\begin{tabular}{ccccc}
\hline & Total & CD138+ & CD138- & Bcl-2-R-R $^{a}$, \\
\hline bcl-6+, bcl-2+, CD10+ & 17 & $3 / 16^{b}$ & $13 / 16$ & $3 / 10$ \\
bcl-6+, bcl-2+, CD10- & 12 & 0 & 12 & $0 / 7$ \\
bcl-6+, bcl-2-, CD10+ & 6 & 0 & 6 & $3 / 9$ \\
bcl-6+, bcl-2-, CD10- & $2^{c}$ & 0 & 2 & $1 / 4$ \\
bcl-6-, bcl-2+, CD10- & 1 & 0 & 1 & $1 / 2$ \\
bcl-6-, bcl-2+, CD10+ & 2 & 0 & 2 & $0 / 0$ \\
\hline
\end{tabular}

${ }^{a}$ Bcl-2R were identified in $1 / 4$ cases not included in this table. The bcl-2R-positive case was bcl-2+, CD138 equivocal and bcl- 6 and CD10 staining could not be tested. One of these cases considered bcl-2R-negative showed a weak mcr rearrangement by Southern blot analysis but it could not be confirmed by polymerase chain reaction. Bcl-6R were identified in 0/4 additional cases.

${ }^{b}$ In one case, the bcl- 6 staining was mostly in CD20+ CD10+ vaguely nodular areas that included multilobate cells and the CD138 positivity was in the intervening areas that were mostly bcl-6 negative, mostly CD20 negative and showed only some CD10 positivity. Bcl-2 staining was more marked in the latter areas also. A bcl-6/CD138 double stain did not demonstrate any definite double-stained cells (data not shown). In the other two cases, the bcl-6 positivity was uniform and the CD138 staining patchy.

${ }^{c}$ One case considered negative showed equivocal bcl-2 staining.

${ }^{d}$ Only includes results for cases with documented immunoglobulin heavy chain rearrangement.

unexplained lack of many immunoblasticappearing cases in our study may have resulted in the high proportion of bcl- $6+$ cases, because bcl- 6 positivity is reported to be less frequent in immunoblastic than in LNC-type DLBCL (39). Among the HIV-associated lymphomas, the bcl-6+/CD138phenotype was also associated with those of large or small noncleaved cell type and considered to be indicative of a FCC stage of differentiation (25). The lower proportion of bcl-6+ DLBCL in some studies also may be explained by technical factors such as artifactual negativity caused by slides sitting out exposed to light for several weeks or the specific antibody used, because the PG-B6 clone may stain cases that are negative using a P1F6 clone (39). As seen here, both nodal and extranodal DLBCL have similar proportions of bcl-6+ cases (39). Bcl-6 mRNA overexpression also clustered with the other germinal center cell markers identified in the DNA microarray study of DLBCL; however, this study would suggest a much lower proportion of FCCtype DLBCL than immunohistologic bcl-6 studies such as ours (44). Bcl-6 mRNA levels, however, are not equivalent to bcl-6 protein expression (as measured here), because germinal center B cells have much greater levels of bcl-6 protein than resting B cells even though they have similar mRNA levels (65). With occasional exceptions, the following nonFCC lymphomas are bcl-6 negative: mantle cell, marginal zone lymphomas of splenic and nonsplenic types and small lymphocytic lymphoma (59, $62)$.

The other major type of B-cell lymphoma reported to be frequently bcl-6-positive is the "high grade MALT" lymphomas $(64,66,67)$. However, these are genotypically distinct from low grade MALT lymphomas, are considered DLBCL in the REAL/WHO classifications and many may represent FCC lymphomas. MALT lymphomas with a high- and low-grade component have also been described where the bcl-6 expression is only in the high grade component (64). This might reflect transformation in follicles in which the neoplastic cells also acquire a more FCC-like phenotype. The suggestion that persistent bcl-6 expression to the plasmacytoid stage of differentiation might follow bcl-6R (42) also raises the possibility that some bcl-6+ neoplasms could be postfollicular in origin. Bcl-6 positivity is also found in the " $\mathrm{L}$ and $\mathrm{H}$ " cells of nodular lymphocyte predominance Hodgkin's lymphoma, in Reed-Sternberg cells in approximately 30 to $42 \%$ of classic Hodgkin's lymphoma and in almost half of anaplastic large-cell lymphomas of T or null-cell type (68-70).

Consistent with the cases reported here, bcl-6R or $3 q 27$ translocations are usually reported to be present in $\sim 25$ to $33 \%$ of DLBCL and reportedly are more often found at relapse $(68 \%)$ than at diagnosis (14\%) $(28,30,35-43)$. These translocations occur in the $5^{\prime}$ flanking region of the gene leaving the coding sequence intact but with the regulatory sequences replaced by heterologous promoters, which leads to deregulated bcl-6 expression (36, 42, 52, 71, 72). Although most commonly associated with translocation to different loci in the immunoglobulin heavy-chain gene, the rearrangements are promiscuous with a variety of partners $(41,42,73)$. Cases with 3q27 abnormalities do not necessarily demonstrate a bcl-6 rearrangement using Southern blot analysis and almost half of cases with molecular evidence of such a rearrangement in one study did not show cytogenetic evidence of a 3q27 abnormality $(36,37,73)$. As in one FL in this study, occasional FL and DLBCL have rearrangements of both bcl-2 and bcl-6 (33, 39, 41, 43). Coexisting bcl-6 and c-myc rearrangements or bcl-6, c-myc and bcl-2 rearrangements in DLBCL are also reported $(33,37$, 40, 74).

Bcl-6 translocations are considered an oncogenic event $(33,53)$. It has been suggested that the bcl- 6 protein "induces lymphomas by regulating the expression of key downstream target genes." (53) and that the translocation may be lymphomagenic by leading to abnormally persistent bcl-6 expression 
which blocks B-cell differentiation in the germinal center (42). Internal deletions in the bcl-6 gene can also lead to deregulation of bcl-6 expression (75).

Bcl-6 translocations do not further clarify the cell of origin of DLBCL. Similar to the $17 \%$ found here, bcl-6 or 3q27 translocations are also reported in $0-19 \%$ of FL with a higher proportion reported in FL of mixed (27\%) or large cell type $(30-40 \%)(28$, $35,36,38,41,76)$. The proportion of DLBCL with a bcl-6 translocation is therefore very similar to the proportion in FL with more numerous LNC/CB. Bcl-6 translocations, however, are not restricted to FCC lymphomas $(77,78)$. They do not correlate with bcl-6 expression nor do they appear to correlate with CD10 expression (25, 39, 57, 59, 60, 63). Whether bcl-6 translocations are a favorable prognostic indicator is controversial $(30,33,37)$. Some but not all authors report an association with extranodal DLBCL $(37,40,41,50)$.

Bcl-6 mutations are also of interest because they are considered indicative of follicular/postfollicular differentiation in normal as well as neoplastic B cells $(72,79-85)$. Bcl-6 mutations are found in very few normal naive B cells or prefollicular mantle cell lymphomas but are present in $\sim 33$ to $50 \%$ of normal FCC and in about 40 to $50 \%$ of FL (and MALT lymphomas) $(35,80,85)$. Peng et al. have suggested that because the mutations are usually outside the motifs potentially important for transcription, they are not lymphomagenic (85). It has also been suggested, however, that accumulating mutations in the bcl-6 regulatory region may be responsible, at least in part, for tumor progression, transformation of FL to DLBCL and the development of AIDSrelated lymphomas $(79,81,84)$. With the exception of primary mediastinal DLBCL, all other types of DLBCL, including those of nodal or extranodal type, show 40 to $>70 \%$ of cases with bcl- 6 mutations, which is relatively similar to the $60 \%$ found in FL (35, 63, 79-81). This supports a follicular/postfollicular origin for many DLBCL, and intraclonal heterogeneity in 1/3 DLBCL is consistent with at least some showing FCC-like ongoing somatic mutation (84).

CD10 (common acute lymphocytic leukemia antigen) is a cell surface metalloproteinase that reduces cellular response to peptide hormones and is found on neutrophils, B lymphoblasts, some T lymphoblasts, normal FCC, and some nonhematopoietic cells $(7,8,10,12)$. Reported CD10 expression in FL has varied widely with most reports describing about 60 to $90 \%$ positive cases $(7,9-11,13)$. DNA microarray analysis also confirms the association of CD10 with other germinal center cell associated genes (44). The observation of CD10 expression by $62 \%$ of the DLBCL studied here further supports a FCC origin for many of the cases and, as suggested by the bcl- 6 results, may be an underestimate con- sistent with the fact that not even all FL are positive. Others have reported up to $56 \%$ of DLBCL to be positive $(7,10-12,60,86,87)$. Whether the few $\mathrm{CD} 10+$ cases lacking bcl- 6 are truly of FCC origin cannot be determined because CD10 expression is also found in other non-FCC B-cell neoplasms including myeloma/plasmacytomas (12). Bcl-2 rearrangement is reported to be more common in the CD10+ DLBCL although not restricted to such cases, further confirming the observation that CD10 expression by itself will underestimate the proportion of DLBCL that are of FCC origin $(32,86)$.

Bcl-2, an antiapoptotic protein, is present in many normal B and T cells; however, most normal FCC lack bcl-2 protein even though they contain abundant bcl-2 mRNA (14, 15, 21, 88, 89). One of the most characteristic feature of FL is the presence of a $t(14 ; 18)(\mathrm{q} 32 ; \mathrm{q} 21)$ reciprocal translocation that involves the bcl-2 gene on chromosome 18 and the immunoglobulin heavy chain gene on chromosome 14 (22, 26-29). Using a variety of methodologies, it is found in most studies in about 60 to $80 \%$ of FL with a higher proportion identified in small cleaved FL than in FL with more numerous LNC/CB (22, 26-29).

FL not only show genotypic abnormalities involving the bcl-2 gene but, in contrast to normal follicles, frequently express the bcl-2 protein. Bcl-2+ neoplastic follicles are present in most, but not all, FL with a $t(14 ; 18)$ and are also present in a minority that lack the translocation $(14-24,29,39)$. Most authors report at least $80 \%$ of FL to be bcl-2positive with a majority of cases showing the most intense staining in the neoplastic follicles (14-24). Grade I FL are the most likely to be bcl-2+ (generally 90 to 100\%), whereas those with more LNC/CB are often reported to be positive in a variable but somewhat lower proportion of cases (generally about 50 to $90 \%$ ) (14-24). Even when positive, these latter cases usually show much greater staining of the small cleaved cells compared with the weak or negative LNC/CB $(20,29)$. Bcl-2 expression, although characteristic of FL, is not a specific marker for FCC neoplasms, because it is expressed by many normal lymphocytes and by many other nonHodgkin's lymphomas that are not of FCC origin and that lack a $\mathrm{t}(14 ; 18)(14,17)$.

Bcl-2 protein was identified in $81 \%$ of the DLBCL studied here. Some authors report a similar proportion of positive cases and others less than $50 \%$ (14, 16, 24, 39, 46-48, 60, 86, 90, 91). Bcl-2 expression does not correlate with either bcl-6 staining or with CD10 expression and is not useful in assessing whether a DLBCL is of FCC origin $(39,86)$. Bcl-2 was expressed by neoplasms with evidence of some postfollicular differentiation and failed to be expressed in some cases with strong evidence for a FCC origin. Consistent with this, bcl-2 expression 
does not correlate with immunoblastic versus LNC/CB differentiation (39). Furthermore, little or no bcl-2 expression may be present even in DLBCL with bcl-2 translocations, perhaps because of mutations in the bcl-2 open-reading frame $(33,47)$. It is of interest that the frequency of bcl-2 expression in DLBCL is similar to grade III FL. Several studies have reported much more frequent bcl-2 expression in nodal compared with extranodal or specifically "high-grade MALT" lymphomas (39, 90, 92). This correlation was not identified here perhaps because a nodal origin for lymphomas present in biopsies of extranodal sites was not rigorously excluded. Bcl-2 expression is of practical importance because it has been reported to be an adverse prognostic indicator in DLBCL (33, 46-49).

In contrast to bcl-2 protein expression, the more specific $t(14 ; 18)$ is found much less frequently in DLBCL than in FL $(22,26-34)$. The reported frequency of bcl-2 translocations in DLBCL varies widely from less than 10 to $\sim 40 \%$ with variables including technical ones as well as the recognition that DLBCL that represent transformation of a preexisting FL will have a higher proportion of bcl-2 rearrangements than those without such a history (83 versus $17 \%)(22,26-34)$. It should also be recognized that sensitive techniques also demonstrate that about half of normal adults have cells in their blood, tonsils, or spleens with bcl-2R, and conversely, genotypic studies using PCR and even SBA will miss varying proportions of cases with a cytogenetically documented $t(14 ; 18)(29,47,93-95)$.

DLBCL with $t(14 ; 18)$ did have phenotypic features further supporting their close relationship to FL including bcl-6 positivity in all the cases we examined and bcl-2 and CD10 expression in all but one. Others have reported bcl-6 negative cases that could represent technical differences or suggest that either bcl-6 negativity does not completely rule out a FCC origin or that $t(14 ; 18)$ in isolation does not necessarily indicate a relationship to a FL (39).

The findings in this and other related studies clearly support that many DLBCL are of FCC origin even though they lack the FL-associated bcl-2 translocation. This observation is consistent with the fact many DLBCL do not arise in the setting of a prior FL. The lower frequency of bcl-2 translocations is also found in FL with more numerous LNC/CB (27). Explanations for the bcl-2 expression in DLBCL of FCC origin that lack the translocation may also help explain their pathogenesis. One such explanation is that 11 to $31 \%$ of DLBCL show highlevel amplification of 18q21-21 or bcl-2, with one study reporting this amplification specificially in cases with high levels of bcl-2 protein that lacked a $t(14 ; 18)(34,91,96,97)$. Somatic mutations of the bcl-2 gene also occur and might lead to aberrant bcl-2 expression in these cases (91).
The literature is contradictory as to the frequency of bcl-2R in nodal versus extranodal lymphomas (30-34). Several studies have suggested rearrangements to be much more common in nodal cases with an absence in stage I DLBCL $(31,33)$. Some DLBCL such as those of primary cutaneous type are reportedly uniformly bcl-2R negative (98). Most authors report that the presence of a bcl-2R in DLBCL does not have prognostic implications (33, 37, 40, $47,48,91)$. The negative impact reported by some in DLBCL might reflect inclusion of more cases that represent transformed low grade FL (91).

CD138, syndecan-1, is a plasma cell-associated transmembrane heparan sulfate proteoglycan that is a low-affinity receptor for basic fibroblast growth factor and extracellular matrix components (99, 100). In addition to plasma cells, CD138 is expressed by pre-B cells, postfollicular immunoblasts, a subset of classic Reed-Sternberg cells and some epithelial cells $(25,70)$. As noted above, CD138 and bcl-6 expression have been used to classify AIDSrelated lymphomas into a germinal center type (Bcl-6+/CD138-) and into a postgerminal center type (Bcl-6-/CD138+, immunoblastic, plasmacytoid, and primary effusion types) (25). A small number of cases were bcl- 6 and CD138 negative as also observed in our study of non-AIDS associated DLBCL. The vast majority of cases in our study were bcl-6+/CD138 - (FCC phenotype) with CD138 expression found only in a minority of DLBCL. Both patients with CD138 expression also had bcl-6 expression. One of these cases suggested differentiation from FCC to postfollicular cells and the other appeared to show expression of both antigens in the same areas with CD138 on a subset of the neoplastic cells. Whereas CD138 and bcl-6 expression in the same case is not described in the AIDSrelated lymphomas, a subset of classic HD demonstrate both bcl-6+/CD138- and bcl-6-/CD138+ Reed-Sternberg cells (70). CD138 and bcl-6 when both present were reported to be mutually exclusive (70).

It is unclear why our unselected series contained so few DLBCL with a postfollicular phenotype. These findings, however, were consistent with the morphologic observations that very few cases appeared immunoblastic. The finding of some immunoblastic-like cases having a FCC phenotype or genotype has also been reported by others (25, 39). DNA microarray analysis with gene expression profiling suggests that about half of DLBCL have a germinal center-like pattern and the others a prognostically adverse pattern more like in vitro activated peripheral blood B cells (44). How these extensive mRNA profiles would correlate with the findings in a study such as this remains to be determined. 
Studies of immunoglobulin (Ig) gene mutational status have also been used to investigate DLBCL because prefollicular B cells have nonmutated immunoglobulin genes and follicular and postfollicular B cells have mutated Ig genes, with ongoing mutations a characteristic, although possibly not completely specific feature, for FCC (101-103). These genotypic studies further confirm that most DLBCL are of FCC origin with frequently mutated Ig genes often showing evidence of positive or negative antigen selection and ongoing mutations (80, 101, 104-110). The lack of ongoing mutations in some series may relate to their being studied mostly at relapse after therapy induced "clonal narrowing" (101). Some mutated cases, however, are consistent with postfollicular B-cell neoplasms as would be expected from this and many other studies.

In summary, these studies, as well as many others, support the heterogeneity of the DLBCL and confirm that more than half have a phenotypic profile characteristic of normal or neoplastic FCC. The bcl-6 findings suggest a much a greater proportion with FCC features; however, this will have to be correlated with other more complex evaluations of FCC derivation. Even if of FCC origin, many DLBCL seem to have a molecular pathogenesis different from most grade I FL but possibly similar to a significant subset of grade II/III FL. The clinical implications for the different subgroups of DLBCL defined in this study remains to be determined.

\section{REFERENCES}

1. Harris NL, Jaffe ES, Stein H, Banks PM, Chan JK, Cleary ML, et al. A revised European-American classification of lymphoid neoplasms: a proposal from the International Lymphoma Study Group. Blood 1994;84:1361-92.

2. Jaffe ES, Harris NL, Diebold J, Muller-Hermelink HK. World Health Organization classification of neoplastic diseases of the hematopoietic and lymphoid tissues. A progress report. Am J Clin Pathol 1999;111(1 Suppl 1):S8-12.

3. Harris NL, Jaffe ES, Diebold J, Flandrin G, MullerHermelink HK, Vardiman J, et al. The World Health Organization classification of hematological malignancies report of the Clinical Advisory Committee Meeting, Airlie House, Virginia, November 1997. Mod Pathol 2000;13:193207.

4. Diebold J, Anderson JR, Armitage JO, MacLennan KA, Muller-Hermelink HK, Nathwani BN, et al. Diffuse aggressive B-cell lymphoma (DABL): A clinicopathologic analysis of 480 cases [abstract]. Mod Pathol 1998;11:128A.

5. Engelhard M, Brittinger G, Huhn D, Gerhartz HH, Meusers $\mathrm{P}$, Siegert W, et al. Subclassification of diffuse large B-cell lymphomas according to the Kiel classification: distinction of centroblastic and immunoblastic lymphomas is a significant prognostic risk factor. Blood 1997;89:2291-7.

6. Anonymous. National Cancer Institute sponsored study of classifications of non-Hodgkin's lymphomas: summary and description of a working formulation for clinical usage. The Non-Hodgkin's Lymphoma Pathologic Classification Project. Cancer 1982;49:2112-35.

7. Almasri NM, Iturraspe JA, Braylan RC. CD10 expression in follicular lymphoma and large cell lymphoma is different from that of reactive lymph node follicles. Arch Pathol Lab Med 1998;122:539-44.

8. Letarte M, Vera S, Tran R, Addis JB, Onizuka RJ, Quackenbush EJ, et al. Common acute lymphocytic leukemia antigen is identical to neutral endopeptidase. J Exp Med 1988; 168:1247-53.

9. Chen C, Raikow, RB, Sonmez-Alpan, E, Swerdlow SH. Classification of small B-cell lymphoid neoplasms using a paraffin section immunohistochemical panel. Appl Immunohistochem Molecul Morphol 2000;8:1-11.

10. McIntosh GG, Lodge AJ, Watson P, Hall AG, Wood K, Anderson JJ, et al. NCL-CD10-270: a new monoclonal antibody recognizing CD10 in paraffin-embedded tissue. Am J Pathol 1999;154:77-82.

11. Kaufmann O, Flath B, Spath-Schwalbe E, Possinger K, Dietel M. Immunohistochemical detection of CD10 with monoclonal antibody 56C6 on paraffin sections. Am J Clin Pathol 1999;111:117-22.

12. Arber DA. CD10 A review. Appl Immunohistochem 1997;5: $125-140$.

13. de Leon ED, Alkan S, Huang JC, Hsi ED. Usefulness of an immunohistochemical panel in paraffin-embedded tissues for the differentiation of B-cell non-Hodgkin's lymphomas of small lymphocytes. Mod Pathol 1998;11:1046-51.

14. Pezzella F, Tse AG, Cordell JL, Pulford KA, Gatter KC, Mason DY. Expression of the bcl-2 oncogene protein is not specific for the 14;18 chromosomal translocation. Am J Pathol 1990; 137:225-32.

15. Utz GL, Swerdlow SH. Distinction of follicular hyperplasia from follicular lymphoma in B5-fixed tissues: comparison of MT2 and bcl-2 antibodies. Hum Pathol 1993;24:1155-8.

16. Ngan BY, Chen-Levy Z, Weiss LM, Warnke RA, Cleary ML. Expression in non-Hodgkin's lymphoma of the bcl-2 protein associated with the $\mathrm{t}(14 ; 18)$ chromosomal translocation. N Engl J Med 1988;318:1638-44.

17. Lai R, Arber DA, Chang KL, Wilson CS, Weiss LM. Frequency of bcl-2 expression in non-Hodgkin's lymphoma: a study of 778 cases with comparison of marginal zone lymphoma and monocytoid B-cell hyperplasia. Mod Pathol 1998;11:864-9.

18. Dogan A, Du MQ, Aiello A, Diss TC, Ye HT, Pan LX, et al. Follicular lymphomas contain a clonally linked but phenotypically distinct neoplastic B-cell population in the interfollicular zone. Blood 1998;91:4708-14.

19. Ashton-Key M, Diss TC, Isaacson PG, Smith ME. A comparative study of the value of immunohistochemistry and the polymerase chain reaction in the diagnosis of follicular lymphoma. Histopathology 1995;27:501-8.

20. Gaulard P, d'Agay MF, Peuchmaur M, Brousse N, Gisselbrecht C, Solal-Celigny P, et al. Expression of the bcl-2 gene product in follicular lymphoma. Am J Pathol 1992;140:1089-95.

21. Veloso JD, Rezuke WN, Cartun RW, Abernathy EC, Pastuszak WT. Immunohistochemical distinction of follicular lymphoma from follicular hyperplasia in formalin-fixed tissues using monoclonal-antibodies Mt2 and Bcl-2. Appl Immunohistochem 1995;3:153-9.

22. Pezzella F, Jones M, Ralfkiaer E, Ersboll J, Gatter KC, Mason DY. Evaluation of bcl-2 protein expression and 14;18 translocation as prognostic markers in follicular lymphoma. $\mathrm{Br}$ J Cancer 1992;65:87-9.

23. Nguyen PL, Zukerberg LR, Benedict WF, Harris NL. Immunohistochemical detection of p53, bcl-2, and retinoblastoma proteins in follicular lymphoma. Am J Clin Pathol 1996;105:538-43.

24. Wheaton S, Netser J, Guinee D, Rahn M, Perkins S. Bcl-2 and bax protein expression in indolent versus aggressive 
B-cell non-Hodgkin's lymphomas. Hum Pathol 1998;29:820-5.

25. Carbone A, Gaidano G, Gloghini A, Larocca LM, Capello D, Canzonieri V, et al. Differential expression of BCL-6, CD138/syndecan-1, and Epstein-Barr virus-encoded latent membrane protein-1 identifies distinct histogenetic subsets of acquired immunodeficiency syndrome-related nonHodgkin's lymphomas. Blood 1998;91:747-55.

26. Weiss LM, Warnke RA, Sklar J, Cleary ML. Molecular analysis of the $t(14 ; 18)$ chromosomal translocation in malignant lymphomas. N Engl J Med 1987;317:1185-9.

27. Lopez-Guillermo A, Cabanillas F, McDonnell TI, McLaughlin P, Smith T, Pugh W, et al. Correlation of bcl-2 rearrangement with clinical characteristics and outcome in indolent follicular lymphoma. Blood 1999;93:3081-7.

28. Garcia-Sanz R, Vargas Montero M, Gonzalez Diaz M, del Carmen M, Santos C, Balanzategui Echevarria A, et al. Detection of single and associated lesions of the Bcl-1, Bcl-2, Bcl-6, c-myc, p53 and p16 genes in B-cell nonHodgkin's lymphomas: value of molecular analysis for a better assignment of the histologic subtype. Haematologica 1998;83:209-16.

29. Seite P, Hillion J, d'Agay MF, Gaulard P, Cazals D, Badoux $\mathrm{F}$, et al. BCL2 gene activation and protein expression in follicular lymphoma: a report on 64 cases. Leukemia 1993; $7: 410-7$.

30. Pescarmona E, De Sanctis V, Pistilli A, Pacchiarotti A, Martelli M, Guglielmi C, et al. Pathogenetic and clinical implications of Bcl-6 and Bcl-2 gene configuration in nodal diffuse large B-cell lymphomas. J Pathol 1997;183:281-6.

31. Raghoebier S, Kramer MH, van Krieken JH, de Jong D, Limpens J, Kluin-Nelemans JC, et al. Essential differences in oncogene involvement between primary nodal and extranodal large cell lymphoma. Blood 1991;78:2680-5.

32. Jacobson JO, Wilkes BM, Kwaiatkowski DJ, Medeiros LJ, Aisenberg AC, Harris NL. bcl-2 rearrangements in de novo diffuse large cell lymphoma. Association with distinctive clinical features. Cancer 1993;72:231-6.

33. Kramer MH, Hermans J, Wijburg E, Philippo K, Geelen E, van Krieken JH, et al. Clinical relevance of BCL2, BCL6, and MYC rearrangements in diffuse large B-cell lymphoma. Blood 1998;92:3152-62.

34. Rao PH, Houldsworth J, Dyomina K, Parsa NZ, Cigudosa JC, Louie DC, et al. Chromosomal and gene amplification in diffuse large B-cell lymphoma. Blood 1998;92:234-40.

35. Migliazza A, Martinotti S, Chen W, Fusco C, Ye BH, Knowles $\mathrm{DM}$, et al. Frequent somatic hypermutation of the $5^{\prime}$ noncoding region of the BCL6 gene in B-cell lymphoma. Proc Natl Acad Sci U S A 1995;92:12520-4.

36. Bastard C, Deweindt C, Kerckaert JP, Lenormand B, Rossi A, Pezzella F, et al. LAZ3 rearrangements in non-Hodgkin's lymphoma: correlation with histology, immunophenotype, karyotype, and clinical outcome in 217 patients. Blood 1994;83:2423-7.

37. Offit K, Lo Coco F, Louie DC, Parsa NZ, Leung D, Portlock C, et al. Rearrangement of the bcl-6 gene as a prognostic marker in diffuse large-cell lymphoma. N Engl J Med 1994; 331:74-80.

38. Otsuki T, Yano T, Clark HM, Bastard C, Kerckaert JP, Jaffe ES, et al. Analysis of LAZ3 (BCL-6) status in B-cell nonHodgkin's lymphomas: results of rearrangement and gene expression studies and a mutational analysis of coding region sequences. Blood 1995;85:2877-84.

39. Skinnider BF, Horsman DE, Dupuis B, Gascoyne RD. Bcl-6 and Bcl-2 protein expression in diffuse large B-cell lymphoma and follicular lymphoma: correlation with 3q27 and 18q21 chromosomal abnormalities. Hum Pathol 1999;30: 803-8.

40. Vitolo U, Gaidano G, Botto B, Volpe G, Audisio E, Bertini M, et al. Rearrangements of bcl-6, bcl-2, c-myc and 6q deletion in B-diffuse large-cell lymphoma: clinical relevance in 71 patients. Ann Oncol 1998;9:55-61.

41. Muramatsu M, Akasaka T, Kadowaki N, Ohno H, Yamabe $\mathrm{H}$, Edamura S, et al. Rearrangement of the BCL6 gene in B-cell lymphoid neoplasms: comparison with lymphomas associated with BCL2 rearrangement. Br J Haematol 1996; 93:911-20.

42. Chen W, Iida S, Louie DC, Dalla-Favera R, Chaganti RS. Heterologous promoters fused to BCL6 by chromosomal translocations affecting band $3 q 27$ cause its deregulated expression during B-cell differentiation. Blood 1998;91:603-7.

43. Butler M, Corbally N, Dervan PA, Carney DN. BCL-6 and other genomic alterations in non-Hodgkin's lymphoma (NHL). Br J Cancer 1997;75:1641-5.

44. Alizadeh AA, Eisen MB, Davis RE, Ma C, Lossos IS, Rosenwald A, et al. Distinct types of diffuse large B-cell lymphoma identified by gene expression profiling. Nature 2000;403:503-11.

45. Lukes RJ, Collins RD. Immunologic characterization of human malignant lymphomas. Cancer 1974;34(4 Suppl): 1488-503.

46. Hermine O, Haioun C, Lepage E, d'Agay MF, Briere J, Lavignac C, et al. Prognostic significance of bcl-2 protein expression in aggressive non-Hodgkin's lymphoma. Groupe d'Etude des Lymphomes de l'Adulte (GELA). Blood 1996; 87:265-72.

47. Gascoyne RD, Adomat SA, Krajewski S, Krajewska M, Horsman DE, Tolcher AW, et al. Prognostic significance of Bcl-2 protein expression and Bcl-2 gene rearrangement in diffuse aggressive non-Hodgkin's lymphoma. Blood 1997;90:24451.

48. Hill ME, MacLennan KA, Cunningham DC, Vaughan Hudson B, Burke M, Clarke P, et al. Prognostic significance of BCL-2 expression and bcl-2 major breakpoint region rearrangement in diffuse large cell non-Hodgkin's lymphoma: a British National Lymphoma Investigation Study. Blood 1996;88:1046-51.

49. Sanchez E, Chacon I, Plaza MM, Munoz E, Cruz MA, Martinez B, et al. Clinical outcome in diffuse large B-cell lymphoma is dependent on the relationship between different cell-cycle regulator proteins. J Clin Oncol 1998;16:1931-9.

50. Liang R, Chan WP, Kwong YL, Xu WS, Srivastava G, Ho FC. High incidence of BCL- 6 gene rearrangement in diffuse large B-cell lymphoma of primary gastric origin. Cancer Genet Cytogenet 1997;97:114-8.

51. Chang CC, Ye BH, Chaganti RS, Dalla-Favera R. BCL-6, a $\mathrm{POZ/zinc-finger} \mathrm{protein,} \mathrm{is} \mathrm{a} \mathrm{sequence-specific} \mathrm{transcrip-}$ tional repressor. Proc Natl Acad Sci U S A 1996;93:6947-52.

52. Ye BH, Cattoretti G, Shen Q, Zhang J, Hawe N, de Waard R, et al. The BCL-6 proto-oncogene controls germinal-centre formation and Th2-type inflammation. Nat Genet 1997;16: 161-70.

53. Staudt LM, Dent AL, Shaffer AL, Yu X. Regulation of lymphocyte cell fate decisions and lymphomagenesis by BCL-6. Int Rev Immunol 1999;18:381-403.

54. Dent AL, Shaffer AL, Yu X, Allman D, Staudt LM. Control of inflammation, cytokine expression, and germinal center formation by BCL-6. Science 1997;276:589-92.

55. Dhordain P, Lin RJ, Quief S, Lantoine D, Kerckaert JP, Evans RM, et al. The LAZ3(BCL-6) oncoprotein recruits a SMRT/ $\mathrm{mSIN} 3 \mathrm{~A} / \mathrm{histone}$ deacetylase containing complex to mediate transcriptional repression. Nucleic Acids Res 1998;26: 4645-51.

56. Miki T, Kawamata N, Arai A, Ohashi K, Nakamura Y, Kato A, et al. Molecular cloning of the breakpoint for 3q27 translocation in B-cell lymphomas and leukemias. Blood 1994;83: 217-22. 
57. Cattoretti G, Chang CC, Cechova K, Zhang J, Ye BH, Falini $\mathrm{B}$, et al. BCL-6 protein is expressed in germinal-center B cells. Blood 1995;86:45-53.

58. Onizuka T, Moriyama M, Yamochi T, Kuroda T, Kazama A, Kanazawa N, et al. BCL-6 gene product, a 92-to 98-kD nuclear phosphoprotein, is highly expressed in germinal center B cells and their neoplastic counterparts. Blood 1995;86:28-37.

59. Flenghi L, Ye BH, Fizzotti M, Bigerna B, Cattoretti G, Venturi S, et al. A specific monoclonal antibody (PG-B6) detects expression of the BCL-6 protein in germinal center B cells. Am J Pathol 1995;147:405-11.

60. Flenghi L, Bigerna B, Fizzotti M, Venturi S, Pasqualucci L, Pileri S, et al. Monoclonal antibodies PG-B6a and PG-B6p recognize, respectively, a highly conserved and a formolresistant epitope on the human BCL-6 protein aminoterminal region. Am J Pathol 1996;148:1543-55.

61. Bajalica-Lagercrantz S, Piehl F, Lagercrantz J, Lindahl J, Weber G, Kerckeart JP, et al. Expression of LAZ3/BCL6 in follicular center (FC) B cells of reactive lymph nodes and FC-derived non-Hodgkin lymphomas. Leukemia 1997;11: 594-8.

62. Raible MD, Hsi ED, Alkan S. Bcl-6 protein expression by follicle center lymphomas. A marker for differentiating follicle center lymphomas from other low-grade lymphoproliferative disorders. Am J Clin Pathol 1999;112:101-7.

63. Larocca LM, Capello D, Rinelli A, Nori S, Antinori A, Gloghini A, et al. The molecular and phenotypic profile of primary central nervous system lymphoma identifies distinct categories of the disease and is consistent with histogenetic derivation from germinal center-related B cells. Blood 1998;92:1011-9.

64. Omonishi K, Yoshino T, Sakuma I, Kobayashi K, Moriyama $\mathrm{M}$, Akagi T. bcl-6 protein is identified in high-grade but not low-grade mucosa-associated lymphoid tissue lymphomas of the stomach. Mod Pathol 1998;11:181-5.

65. Allman D, Jain A, Dent A, Maile RR, Selvaggi T, Kehry MR, et al. BCL-6 expression during B-cell activation. Blood 1996; 87:5257-68.

66. De Wolf-Peeters C, Achten R. The histogenesis of large-cell gastric lymphomas. Histopathology 1999;34:71-5.

67. Gaidano G, Capello D, Gloghini A, Fassone L, Vivenza D, Ariatti C, et al. Frequent mutation of bcl-6 proto-oncogene in high grade, but not low grade, MALT lymphomas of the gastrointestinal tract. Haematologica 1999;84:582-8.

68. Falini B, Bigerna B, Pasqualucci L, Fizzotti M, Martelli MF, Pileri S, et al. Distinctive expression pattern of the BCL-6 protein in nodular lymphocyte predominance Hodgkin's disease. Blood 1996;87:465-71.

69. Carbone A, Gloghini A, Gaidano G, Dalla-Favera R, Falini B. BCL-6 protein expression in human peripheral T-cell neoplasms is restricted to CD30+ anaplastic large-cell lymphomas. Blood 1997;90:2445-50.

70. Carbone A, Gloghini A, Gaidano G, Franceschi S, Capello D, Drexler HG, et al. Expression status of BCL-6 and syndecan-1 identifies distinct histogenetic subtypes of Hodgkin's disease. Blood 1998;92:2220-8.

71. Ye BH, Chaganti S, Chang CC, Niu H, Corradini P, Chaganti RS, et al. Chromosomal translocations cause deregulated BCL6 expression by promoter substitution in B cell lymphoma. EMBO J 1995;14:6209-17.

72. Gaidano G, Capello D, Gloghini A, Pastore C, Migliazza A, Quattrone S, et al. BCL-6 in aids-related lymphomas: pathogenetic and histogenetic implications. Leuk Lymphoma 1998;31:39-46.

73. Michaud GY, Gascoyne RD, McNeil BK, Anderson ME, Horsman DE. Bcl-6 and lymphoproliferative disorders. Leuk Lymphoma 1997;26:515-25.

74. Au WY, Gascoyne RD, Viswanatha DS, Skinnider BF, Con- nors JM, Klasa RJ, et al. Concurrent chromosomal alterations at 3q27, 8q24 and 18q21 in B-cell lymphomas. Br J Haematol 1999;105:437-40.

75. Nakamura Y, Saito K, Furusawa S. Analysis of internal deletions within the BCL6 gene in B-cell non-Hodgkin's lymphoma. Br J Haematol 1999;105:274-7.

76. Lo Coco F, Ye BH, Lista F, Corradini P, Offit K, Knowles DM, et al. Rearrangements of the BCL6 gene in diffuse large cell non-Hodgkin's lymphoma. Blood 1994;83:1757-9.

77. Dierlamm J, Pittaluga S, Stul M, Wlodarska I, Michaux L, Thomas J, et al. BCL6 gene rearrangements also occur in marginal zone B-cell lymphoma. Br J Haematol 1997;98: 719-25.

78. Miura I, Ohshima A, Chubachi A, Nimura T, Komatsuda A, Utsumi S, et al. BCL6 rearrangement in a patient with mantle cell lymphoma. Ann Hematol 1997;74:247-50.

79. Capello D, Vitolo U, Pasqualucci L, Quattrone S, Migliaretti G, Fassone L, et al. Distribution and pattern of BCL-6 mutations throughout the spectrum of B-cell neoplasia. Blood 2000;95:651-9.

80. Pasqualucci L, Migliazza A, Fracchiolla N, William C, Neri A, Baldini L, et al. BCL-6 mutations in normal germinal center B cells: evidence of somatic hypermutation acting outside Ig loci. Proc Natl Acad Sci U S A 1998;95:11816-21.

81. Gaidano G, Carbone A, Pastore C, Capello D, Migliazza A, Gloghini A, et al. Frequent mutation of the $5^{\prime}$ noncoding region of the BCL- 6 gene in acquired immunodeficiency syndrome-related non-Hodgkin's lymphomas. Blood 1997; 89:3755-62.

82. Gaidano G, Capello D, Cilia AM, Gloghini A, Perin T, Quattrone S, et al. Genetic characterization of HHV-8/KSHVpositive primary effusion lymphoma reveals frequent mutations of BCL6: implications for disease pathogenesis and histogenesis. Genes Chromosomes Cancer 1999;24:16-23.

83. Shen HM, Peters A, Baron B, Zhu X, Storb U. Mutation of BCL-6 gene in normal B cells by the process of somatic hypermutation of Ig genes. Science 1998;280:1750-2.

84. Lossos IS, Levy R. Mutation analysis of the 5 ' noncoding regulatory region of the BCL- 6 gene in non-Hodgkin lymphoma: evidence for recurrent mutations and intraclonal heterogeneity. Blood 2000;95:1400-05.

85. Peng HZ, Du MQ, Koulis A, Aiello A, Dogan A, Pan LX, et al. Nonimmunoglobulin gene hypermutation in germinal center B cells. Blood 1999;93:2167-72.

86. Fang JM, Finn WG, Hussong JW, Goolsby CL, Cubbon AR, Variakojis D. CD10 antigen expression correlates with the $\mathrm{t}(14 ; 18)(\mathrm{q} 32 ; \mathrm{q} 21)$ major breakpoint region in diffuse large B-cell lymphoma. Mod Pathol 1999;12:295-300.

87. Nakamine H, Bagin RG, Vose JM, Bast MA, Bierman PJ, Armitage JO, et al. Prognostic significance of clinical and pathologic features in diffuse large B-cell lymphoma. Cancer 1993;71:3130-7.

88. Reed JC. Bcl-2 family proteins: regulators of apoptosis and chemoresistance in hematologic malignancies. Semin Hematol 1997;34(4 Suppl 5):9-19.

89. Hockenbery DM, Zutter M, Hickey W, Nahm M, Korsmeyer SJ. BCL2 protein is topographically restricted in tissues characterized by apoptotic cell death. Proc Natl Acad Sci U S A 1991;88:6961-5.

90. Piris MA, Pezzella F, Martinez-Montero JC, Orradre JL, Villuendas R, Sanchez-Beato M, et al. p53 and bcl-2 expression in high-grade B-cell lymphomas: correlation with survival time [published erratum appears in Br J Cancer 1994; 69:978]. Br J Cancer 1994;69:337-41.

91. Monni O, Franssila K, Joensuu H, Knuutila S. BCL2 overexpression in diffuse large B-cell lymphoma. Leuk Lymphoma 1999;34:45-52.

92. Villuendas R, Piris MA, Orradre JL, Mollejo M, Rodriguez R, Morente M. Different bcl-2 protein expression in high- 
grade B-cell lymphomas derived from lymph node or mucosa-associated lymphoid tissue. Am J Pathol 1991;139: 989-93.

93. Ji W, Qu GZ, Ye P, Zhang XY, Halabi S, Ehrlich M. Frequent detection of bcl-2/JH translocations in human blood and organ samples by a quantitative polymerase chain reaction assay. Cancer Res 1995;55:2876-82.

94. Aster JC, Kobayashi Y, Shiota M, Mori S, Sklar J. Detection of the $t(14 ; 18)$ at similar frequencies in hyperplastic lymphoid tissues from American and Japanese patients. Am J Pathol 1992;141:291-9.

95. Liu Y, Hernandez AM, Shibata D, Cortopassi GA. BCL2 translocation frequency rises with age in humans. Proc Natl Acad Sci U S A 1994;91:8910-4.

96. Monni O, Joensuu H, Franssila K, Klefstrom J, Alitalo K, Knuutila S. BCL2 overexpression associated with chromosomal amplification in diffuse large B-cell lymphoma. Blood 1997;90:1168-74.

97. Monni O, Joensuu H, Franssila K, Knuutila S. DNA copy number changes in diffuse large B-cell lymphoma-comparative genomic hybridization study. Blood 1996;87:526978.

98. Geelen FA, Vermeer MH, Meijer CJ, Van der Putte SC, Kerkhof E, Kluin PM, et al. bcl-2 protein expression in primary cutaneous large B-cell lymphoma is site-related. J Clin Oncol 1998;16:2080-5.

99. Witzig TE, Kimlinger $\mathrm{T}$, Stenson $\mathrm{M}$, Therneau $\mathrm{T}$. Syndecan-1 expression on malignant cells from the blood and marrow of patients with plasma cell proliferative disorders and B-cell chronic lymphocytic leukemia. Leuk Lymphoma 1998;31:167-75.

100. Wijdenes J, Vooijs WC, Clement C, Post J, Morard F, Vita N, et al. A plasmocyte selective monoclonal antibody (B-B4) recognizes syndecan-1. Br J Haematol 1996;94:318-23.

101. Stevenson F, Sahota S, Zhu D, Ottensmeier C, Chapman C, Oscier D, et al. Insight into the origin and clonal history of B-cell tumors as revealed by analysis of immunoglobulin variable region genes. Immunol Rev 1998;162:247-59.
102. Klein U, Goossens T, Fischer M, Kanzler H, Braeuninger A, Rajewsky K, et al. Somatic hypermutation in normal and transformed human B cells. Immunol Rev 1998;162:261-80.

103. Pascual V, Liu YJ, Magalski A, de Bouteiller O, Banchereau J, Capra JD. Analysis of somatic mutation in five B cell subsets of human tonsil. J Exp Med 1994;180:329-39.

104. Taniguchi M, Oka K, Hiasa A, Yamaguchi M, Ohno T, Kita K, et al. De novo CD5+ diffuse large B-cell lymphomas express $\mathrm{VH}$ genes with somatic mutation. Blood 1998;91:1145-51.

105. Ottensmeier CH, Thompsett AR, Zhu D, Wilkins BS, Sweetenham JW, Stevenson FK. Analysis of VH genes in follicular and diffuse lymphoma shows ongoing somatic mutation and multiple isotype transcripts in early disease with changes during disease progression. Blood 1998;91:4292-9.

106. Hsu FJ, Levy R. Preferential use of the VH4 Ig gene family by diffuse large-cell lymphoma. Blood 1995;86:3072-82.

107. Brauninger A, Kuppers R, Spieker T, Siebert R, Strickler JG, Schlegelberger B, et al. Molecular analysis of single B cells from T-cell-rich B-cell lymphoma shows the derivation of the tumor cells from mutating germinal center B cells and exemplifies means by which immunoglobulin genes are modified in germinal center B cells. Blood 1999;93:267987.

108. Kuppers R, Rajewsky K, Hansmann ML. Diffuse large cell lymphomas are derived from mature B cells carrying $\mathrm{V}$ region genes with a high load of somatic mutation and evidence of selection for antibody expression. Eur J Immunol 1997;27:1398-405.

109. Thompsett AR, Ellison DW, Stevenson FK, Zhu D. V(H) gene sequences from primary central nervous system lymphomas indicate derivation from highly mutated germinal center B cells with ongoing mutational activity. Blood 1999;94: $1738-46$.

110. Lossos IS, Okada CY, Tibshirani R, Warnke R, Vose JM, Greiner TC, et al. Molecular analysis of immunoglobulin genes in diffuse large B- cell lymphomas. Blood 2000;95: $1797-803$ 